Bulletin of Advanced English Studies - Vol. 3, No. 1 , 2019, pp. 21-33

e-ISSN 2617-6459, p-ISSN 2617-6440

Available online at http:// www.refaad.com

https://doi.org/10.31559/baes2019.3.1.3

\title{
Domestication of English Expressions Used by Iraqi Arabic Speakers: A Sociolinguistic Study
}

\author{
Prof. Dr. Ahmed Sahib Mubarak \\ University of Babylon, Faculty of Education for Human Sciences, Department of English, Iraq, Babil \\ asjam72@gmai1.com
}

\section{Lecturer Basim Jubair Kadhim}

Islamic University, Faculty of Education, Department of English, Iraq, Holy Najaf

basimjubair1984@gmai1.com

\begin{abstract}
This paper deals with the process of domestication of English expressions as a sociolinguistic phenomenon. It aims to explore the reasons of domesticating foreign [English] expressions that are variously acculturated within such social variables as gender, age, and social status. A modified sociolinguistic interview has been conducted to take the most frequently domesticated expressions in order to be included in a questionnaire administered to different sample of the Iraqi-Najafi Arabic speakers. The questionnaire is used to support the interview in fulfilling the aims of the research. Throughout the discussions, certain conclusions have been observed. English expressions are domesticated as a strategy of globalization and Englishization. Another considerable conclusion is that females have used domesticated expressions as a way to show prestige and acculturation.
\end{abstract}

Keywords: Sociolinguistics, Domestications, Iraqi-Najafi Dialect, Englishization, Acculturation.

\section{Introduction}

Domestication is a strategy of translation and acculturation. As an acculturation strategy, it is employed to make any given expression conformed to the culture and linguistic system of the native language (Venuti, 1995: 36), such as the English word "connect" which is domesticated by the Iraqi Arabic speakers as كنك، كنكت، كنكو ... Speakers adopt many foreign expressions as a way of achieving an accurate, understandable channel of communication (Dossoumou, 2017: 73). Iraqi speakers follow such a norm in which certain foreign expressions are domesticated to serve their communicative events.

This study tries to address the issue of the sociolinguistic reasons to domesticate the English expressions as a broad strategy and the sociolinguistic variables of language users that affect the use of domestication.

Certain objectives are outlined in this study, one of which is to discover the purposes behind using the domesticated expressions from the English language by Iraqi speakers. Another objective is to deal with the impact of domestication of the English expressions on the sociolinguistic variables in the Iraqi society.

Achieving the objectives above, quantitative as well as qualitative techniques are employed. Data are collected from the spontaneous daily communications among Iraqi people. The steps followed to achieve the objectives of this study are: (1) selecting frequently used English 
domesticated expressions; (2) describing them; (3) tape-recording and extracting the domesticated expressions; and (4) doing the analysis.

\section{Domestication}

Domestication is a strategy mostly used in translation; this means that the expression is made compatible with the target language according to its grammatical system, though it may lose certain information from the source language (Venuti, 1995: 36).

According to Adegbija (2004: 3), domestication is manifested as a sociolinguistic view which means the same as acculturation: a process of sociology in which people use certain cultural features that belong to other groups for interaction. In this sense, domestication could be viewed as a sociolinguistic phenomenon as labelled by Ojidahun (2014: 84), adding that the phenomenon in question directly deals with the codification of new terms to serve certain communicative events. In other words, the main reason behind borrowing a foreign expression and domesticating it is to serve social communicative ends.

Otor (2015: 165) introduces domestication as a factor of creolization in that the term might acquire new phonological modifications if not morphological and syntactic ones. This indicates that domestication involves lexical, semantic, and idiomatic levels. These expressions can be turned out to be autonomous from their source language to become part of the system of the target language (ibid).

Speaking of language enrichment, Olanipekun et al. (2016: 30) focus on domestication as a significant factor for the speaker's innovation and language borrowing. In the same stream, domestication should be contextualized within social situations (ibid).

Dossoumou (2017:73) argues that domestication is a sociolinguistic process of indigenizing and developing languages as it enriches and leads language as a whole to the state of Englishization. Appraising foreign domestication, it is attained that expressions are domesticated for societal reasons, i.e., social activities that have no counterparts are contextualized into the new sociolinguistic situations (Pereira, 2018: 489-490).

\section{Domestication and Foreignization}

Domestication is viewed as a broad translation strategy that is used to acculturate foreign terms into the target language (Venuti, 1995:36). Accompanied by domestication is the process of foreignization which is the opposite of domestication. It is defined as the use of certain expressions from the source language to be employed by the target language (ibid).

The relationship between domestication and foreignization is demonstrated through the directionality; meaning that both processes can deal with the source and target language. However, when one uses the source language expressions, emphasizing the cultural considerations in the target language, then foreignization is manifested. On the other hand, when one employs foreign expressions from the source language to the target one, then, it is the direction toward domesticated expressions (ibid:37).

On the same stream, Rubel and Rosman (2003:11) indicate that these two strategies are used for cultural adjustment and social accommodation as a matter of acculturation and solidification of the language in question.

Although both of these socio-cultural strategies deal with importing and exporting certain linguistic expressions, they have their sub-strategies. These strategies can be the distinctive features of each of these two socio-cultural concepts.

For domestication, Islamein and Javankhlah (2018:167) assert that translators can use specific strategies as explanations, cultural equivalence, cultural adjustment, figurative expressions of non- 
figurative expressions, addition, deletion, euphemism, and syntactical adjustments. As far as foreignization is concerned, loan words or sometimes transliterations, calques translation and literal translation are all employed (ibid).

Accordingly, the majority of the researchers who have been dealing with domestication and foreignization as a strategy ascribe them to society and culture. Najim (2013:510) mentions this as a conclusion, emphasizing that adopting these two strategies is resorted to because of the needs of societies.

\section{Domestication in Society}

Any society uses language in a way that requires serving socio-cultural contexts, in the sense that language is designed for sociolinguistic reasons as a dynamic entity (Holemes, 2013:53). Following such reasoning has a particular sort of cue that the treatment of linguistic phenomena is due to social considerations rather than any other reason.

To strengthen language is to borrow from other languages, a matter that serves socially in the first place. In this regard, domestication is one of the broad strategies that are adopted by society for certain uses, following Hudson (2001:10).

Based on Hymes' (1972) communicative competence, society can use special kind of codification in order to reflect an appropriate competence that is compatible with the foreign words that are domesticated. This can be done through the process of codification at all the linguistic levels such as phonological, morphological, and the syntactical levels, leaving the lexical level as it is or with slight changes (Fasold, 1984).

Convincingly, Baker and Jones (1998:12) draw upon the opinion mentioned above and add that the purpose of domesticating foreign expressions can be due to code-switching of bilinguals; meaning that speakers use different varieties in various cultural contexts which need emphasis on certain expressions.

Dealing with language as a national treasure, Wright (2004:12) argues that language can be modified under the title of nationalism, in the sense that using one language out of different variants is because of the one nation. This language should be homogenous and domesticated for communication. This study focuses on the English language as the colonial language to be localized.

\section{Englishization in Iraqi Society}

Englishization is perceived as a sub-system integrated within the language system as a whole, meaning that it occurs on the phonological, lexical, syntactic and discourse levels. This indicates that language change comes from language contact and language convergence. (Jia-ling, 1994: 167).

According to Crystal (2001), English has become the most widespread language in the globe because of the significant increase of the internet use and users. Since the dominant language of the internet is English, most users tend to pick up English terms and localize them within their source language system.

Dor (2004:115) believes that Englishization is somewhat a hidden hand that causes the native speakers of different languages to turn away from the riches of their languages and blindly follow the English language for the easiness of the terms used. This brings the chance to the English language to become the dominant language in the world.

Shchugurernsky (2007) describes the process of Englishization as a dynamic one in a multilingual society, a matter which can be changed and adjusted with the phonological, lexical, and syntactic levels.

Altabach(2010:33) provides other justifications for the spread of the process of Englishization such as the need of English in education and technology, emphasizing the fast advancement in 
technology that causes language to lag behind in terms of finding out better terms than the English ones.

In studying the impact of English on Pakistani societies, Ashraf and Tsegay (2016: 80) attain that, through globalization and international communication, English has become the source of penetration to the world languages, they (ibid) add that English is part of the global socio-economic institutions that govern the world.

Such an impact necessities the governments to use English - as a powerful hegemony tool- to be used as a second language inside schools, colleges, and other institutions as well as outside of the institutions, i.e., in society (ibid: 82 ).

Ashraf and Tsegay (2016: 86) conclude that the process of Engishization can be employed in the local competition and social status as a means of using prestigious language, another part of the conclusion is the need for the terms that cannot be found in the second language.

Iraqi society is full of English terms used by Iraqi speakers as borrowed words that are adjusted according to the phonological, morphological and syntactic system of the Iraqi Arabic language. AlHindawi and Abukrooze (2016: 65) introduce an analysis of the loanwords in terms of phonological adjustments in the Iraqi Arabic. In their study (ibid), they present a set of English words that have been adopted by the Iraqi society to be used in the daily communication, such words as "cup (كوب), radio (راديو), telephone (تلفون), toilet (تواليت) ...etc. (ibid: 87).

Dossoumou (2017: 67) defines Englishization as the process of using the English words along with their meanings and cultural loads in another language in a way that affects that language. It could be a variety of certain kind that largely depends on common variables such as age, gender, education, class, and status.

In the same stream, Salman and Mansoor (2017:284) deal with the loanwords through the process of Englishization and how such borrowed words can affect the use of the Iraqi Arabic

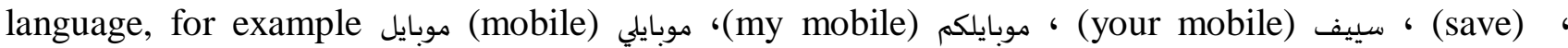
جييك(check). This justifies the use of the English language by the Iraqi Arabic speakers as a process of Englsihization. The reason behind using English expressions is that there is no Arabic equivalent to the englishzed expressions that are used in the Iraqi society (ibid: 285).

It can be commented here that the above two studies indicate the influence of the Iraqi Arabic speakers by the spread of the English language as a global, technological means of communication that has its purposes in the society.

\section{Methodology}

The data are collected from the Iraqi dialect represented by Al-Najaf Al-Ashraf region which is a representative of the Middle-Euphrates part of Iraq. Data, which are taken from people of different levels and categories, are obtained through a kind on interview viz. focus group interviews which are about the significant topic where English is domesticated. However, the interviewees are not informed about the exact reason for having the interview so that the informants use the domesticated expressions spontaneously, following Labov 1984, and to get rid of the observer's paradox.

The informants are of four categories including young, old, males and females, as follows:

1. Young people whose age is between 20 to 35 males.

2. Young people whose age is between 20 to 35 females.

3. Older people whose age is between $35-55$ males

4. Older people whose age is between 35 to 55 males.

Certain questions are asked in order for the focus interviewees to answer them. These questions are limited to four technological areas: mobile phones, the internet, computer, and social 
media. Through answering such questions, the domesticated expressions will be manifested. All the informants' answers are recorded and transcribed, taking into consideration all relevant words and expressions that have been used by the sample. The expressions are categorized further according to the age variable and gender variable.

It is essential to administer a questionnaire for the sake of the reasons why using such domesticated expressions and to what extent they are used, as mentioned in the objectives of the current study. The questionnaire is administered to another group which is not like the focus interviewees. The questionnaire consists of specific items that can be complementary to the interviews. It is also vital to ask the focus group about the education and job of the informants so that it is easy to obtain certain generalizations about the social class. Having all the data collected, transcribed and categorized, data description and analysis are conducted. The description draws on the quantitative as well as the qualitative techniques to support the results of each other and to have as accurate generalizable statements as possible.

Data are collected from two sources, viz. interviews distributed to the four focus groups, as mentioned in the previous section and the questionnaire.

As far as the interview is concerned, questions regarding the mobile phone, the internet, social media, and computer are asked to all the participants and according to the categories in the study. Ten informants of each group have been interviewed. Though answering the questions of the interview by the informants, they spontaneously use many domesticated English expressions which are distributed in all the four fields. Each interview lasts thirty minutes where all the participants have taken their part. All the participants are from the Iraqi province of Najaf. The four groups that have been selected to be interviewed are not the same four groups that have been selected to have the questionnaire, for the sake of accuracy. The domesticated expressions are used differently by the different categories; a matter that indicates the variety of functions in using such domesticated expressions. Certain social variables such as age and gender play an important role in using domesticated English expressions.

As far as the questionnaire is concerned, it consists of ten items within sub-items distributed to cover the range of purposes that the questionnaire is set for. The subjects are classified into four groups. Each group consists of ten respondents, varying according to age and gender. The first four items in the questionnaire are intended to check whether the respondents know the domesticated English words that are used in the four fields. The second four items are concerned with the purpose of why such domesticated expressions are used. The last two items are to check how the domesticated words are integrated within the linguistic system of the target language.

\section{Data Analysis}

In this section, data that have been collected from the interview, as well as the data obtained from the questionnaire, are analyzed.

Regarding the data which have been obtained from the interview, the participants use many domesticated English expressions which are mostly treated like the Iraqi Arabic ones in terms of the morphology, phonology, and syntax. A hundred and one domesticated expressions have been transcribed from the tape recordings. These domesticated expressions are listed according to the four fields that are concerned with the information technology jargon, i.e., computer, mobile phone, the internet, and social media. This number of the domesticated words is obtained during the two hours recordings of the four interviews. Table (1) shows the expressions that have been identified by the researchers through the interview, as demonstrated in appendix (1).

As far as the questionnaire is concerned, the respondents have variously answered regarding the four parts of the questionnaire. The first four items show that the respondents have used certain domesticated expressions - among the ones that have been listed in Table (1). The respondents 
repeat some of the expressions which can be used in two or three or all of the four fields as these expressions are common to some or all of the four fields.

The first four items are about the awareness of the respondents of the domesticated English expressions. All respondents have used 83 domesticated expressions out of the ones listed in Table 1. The first two groups whose age is from 15 to 30, males and females have employed more domesticated expressions than the other two groups, which employed only 57 domesticated expressions, the female group has used 33 while the male group has used 24 domesticated expressions. The other two groups have used 26. The male group has used 15 while the female group has used only 11 . Below is the table of overall results of the analysis in percentages.

Table(1): Percentages of the Overall Use of Domesticated Expressions

\begin{tabular}{|c|c|c|c|c|}
\hline Age & \multicolumn{2}{|c|}{ 20-35 } & \multicolumn{2}{c|}{ 35-55 } \\
\hline Category / Gender & male & female & Male & female \\
\hline Mobile & $78 \%$ & $83 \%$ & $62 \%$ & $56 \%$ \\
\hline Social media & $80 \%$ & $88 \%$ & $59 \%$ & $50 \%$ \\
\hline Internet & $84 \%$ & $89 \%$ & $60 \%$ & $56 \%$ \\
\hline Computer & $85 \%$ & $87 \%$ & $60 \%$ & $54 \%$ \\
\hline Total & $87.42 \%$ & $89.60 \%$ & $61.81 \%$ & $55.62 \%$ \\
\hline
\end{tabular}

The second eight items show many reasons why Iraqi Arabic speakers use domesticated words. $26 \%$ of the respondents justified their use of the domesticated expression saying that there are no Arabic equivalents. 22\% of the respondents said that they use some English expressions because English has become the international language of information technology in addition to the issue of globalization. $19 \%$ of the respondents justified their use of the domesticated English expressions to the issue of semantic load (i. e.) these expressions better convey the meanings they want to express. $17 \%$ of the respondents claim that these expressions are borrowed from English into Arabic due to the lack of coining new suitable words in the Arabic language. The rest of the respondents (i. e. 16\%) believe that Arabic is an old-fashioned language and the use of the domesticated expressions is due to the desire for a prestigious language used by the upper classes. Table (2) summarizes the five reasons with their percentages.

Table(2): Percentage of the Reasons Why Using Domesticated Expressions

\begin{tabular}{|c|c|c|}
\hline NO & Reason & Percentage \\
\hline 1 & No Arabic equivalent & $26 \%$ \\
\hline 2 & $\begin{array}{c}\text { English as international, global language of information } \\
\text { technology }\end{array}$ & $22 \%$ \\
\hline 3 & Better expressed in English & $19 \%$ \\
\hline 4 & Coining new words in Arabic & $17 \%$ \\
\hline 5 & Arabic as an old fashion language & $16 \%$ \\
\hline
\end{tabular}

Concerning the last two items in the questionnaire, the respondents answered them with a high percentage (i. e.) $86 \%$. The answers can be included within the system of the Arabic language as follows:

a. phonological adjustments which indicate that the domesticated English expressions are modified according to the Iraqi Arabic dialect, such as pronouncing /p/ instead of $/ \mathrm{b} /$.

b. Morphological adjustments which refer to the process of applying the morphological system of the

Iraqi Arabic dialect to the domesticated expressions such as the systems of number, gender, 
possession, definiteness, negation and word formation processes such as nouns, verbs, and adjectives. For example, the English word is domesticated into Arabic as (مسجلي مسج) مسجات، (مسج)

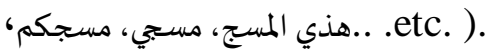

\section{Discussions}

Based on the data that have been analyzed through the interviews and the questionnaire, Iraqi Arabic speakers in the region of Al-Najaf l-Ashraf tend to use English foreign expressions under the process of domestication. The process of domestication is conveyed through stages in the sense that the Iraqi Najafi dialect applies all levels of phonology, morphology, and syntax of the Iraqi dialect to such domesticated expressions. This agrees with most definitions and explanations introduced by Adegijia (2004: 3).

As for the interview, out of the two hours in which about a great deal of the Iraqi dialect has got many domesticated expressions. This indicates that Iraqi Najafi speakers tend to use more English domesticated words than Arabic ones. In the same way, the four items in the questionnaire have provided reasons why such domesticated expressions are used. To state that due to the lack of Iraqi Arabic of the equivalent expressions or the difficulty to find the suitable expression to be used in the society, domesticated expressions are used. For this reason, Iraqi Najafi speakers resort to the English language. This can go hand in hand with Otor (2016) and Dossoumou (2017: 73) who argue that domestication as a process of creolization takes place through the speaker's innovation.

Domesticated expressions, nevertheless, can be used as a substituent for coining new words in Arabic as it is an old language which cannot coin new words, based on the respondent's answers (a point of view which is not adopted by the researchers). This claim can be explained, as Olanipeckun et al. (2016) mention, as a matter of dealing with the fast advancement in the technology that the Arabic society is in desperate need for words to refer to new concepts and devices. Other languages such as Arabic (with its dialects such as Iraqi dialect) cannot quickly catch up the recent advancements, that is why its users resort to domestication.

In terms of merging the domesticated expressions, not the target language as argued by Salman and Mansoor (2017: 284), Iraqi Arabic speakers apply the rules of phonology, morphology, and syntax to all such domesticated expressions. Such an indication brings Iraqi dialect to separation from other dialects to be included as a unique variety which is far from the classical Arabic. The emergence of new domesticated vocabulary enriches the Iraqi dialect to the extent that it could give this dialect a new, distinctive status.

On the level of certain social variables; precisely age and gender, both the interviews and the questionnaire have yielded different results when it comes to the two genders and two categories of age. In terms of the two genders, as Labov (1984) and Holmes (2013) attain, women use more polite and prestigious expressions that men, here women regard the use of domesticated expressions as a matter of a prestigious use. Contrary to that, at an older age, the matter is entirely different. Women pay very little attention to such domesticated words. It can be argued that they have no concern with the fields that have recently emerged so they are in no need for new domesticated expressions.

\section{Conclusions}

Based on the discussions above, the present study has come up with the following conclusions:

As a sociolinguistic phenomenon, domestication is employed by the Iraqi Arabic users as a strategy that refers to new referents that are not found at least in the Iraqi dialect. Often, certain domesticated expressions have their equivalents in Arabic, but Iraqi users feel that it is easier to use the domesticated expressions. 
Domestication is a broad strategy that helps English in the process of Englishization. This is related to the status of the English language as a global, international code of communication, especially in the language of technology.

Regarding the inner circle system of the Iraqi Arabic dialect without any other linguistics system than the lexical one, the domesticated expressions acquire all the rules of the Iraqi Arabic; rules of phonology, morphology, and syntax.

The process of domestication is used more by Iraqi young males and females than the elder ones. This indicates that domestication brings the English culture to be melted into the Arabic culture, especially the Iraqi culture.

According to gender, females in the age 20-35 use domesticated expressions more than males which enhance the idea of acculturation and prestige inside the Iraqi society.

Domestication can be regarded as a vital factor in the language, leading to borrow, modify, and coin new adaptations to certain domesticated expressions.

\section{Biography:}

\section{Prof. Ahmed Sahib Mubarak.}

PhD in English Language and Linguistics, majoring in Applied Sociopragmatics. Faculty Member at the Department of English, College of Education for Human Sciences, University of Babylon. So far published nineteen papers and other four under publication in the fields of sociopragmatics, pragmatics, sociolinguistics, and discourse analysis. Have been teaching and supervising MA and PhD students since 2016.

\section{Lect. Basim Jubair Kadhim}

A PhD candidate majoring in English Language and Linguistics, Pragmatics, a Faculty Member at the Department of English, College of Education, Islamic University. A board member of Iraqi Translation Association, having several papers published in linguistics, pragmatics, translation and stylistics.

\section{References:}

[1] Adegbija. E., The Domestication of English in Nigeria, in Awonusi, S. and Babalola, E.A (eds) the Domestication of English in Nigeria Lagos: University Press, (2004)

[2] Al-Hindawi. F. \& Abukrooze. H., The Phonological Adjustments of English Loan Words to the Iraqi Phonology, in Al-Hindawi, F. and Al-Juwaid, R. (eds): Phonology: Different Dimensionsin: Scholars' Press, (2016)

[3] Altbach. P. G., Reisberg. L., \& Rumbley. L. E., Tracking a global academic revolution, Change: The Magazine of Higher Learning, 42(2)(2010), 30-39, https://doi.org/10.1080/00091381003590845

[4] Ashraf. M. \& Tsegay. S., Analysis of globalization and "Englishization" in Pakistan, International Journal of Research Studies in Language Learning, 4(5)(1)(2016), 79-88, https://doi.org/10.5861/ijrsll.2015.1205

[5] Baker. C. \& Jones. S.P., Encyclopedia of Bilingualism and Bilingual Education, Clevedon: Multilingual Matters, (1998)

[6] Crystal. David., Language and the Internet, Cambridge, UK: Cambridge University Press,(2001)

[7] Dor. D., From Englishization to Imposed Multilingualism: Globalization, the Internet, and the Political Economy of the Linguistic Code, In Public Culture, 16 (1)(2004), 97-118, https://doi.org/10.1215/08992363$16-1-97$ 
[8] Dossoumou. A., Appraising English Domestication in Indigenous Languages among the Benin-Nigeria Border Speech Communities: A Sociolinguistic Perspective, American Journal of Linguistics, 5(3)(2017) 65-74.

[9] Eslamieh. R. \& Javankhah. N., Domestication and Foreignisation in Dubbing and Subtitling of Duncan Jones, English Movie Warcraft into Persian, International Journal of English Language \& Translation Studies. 6(1)(2018),162-170.

[10] Fasold, The sociolinguistics of society. Oxford and New York: Basil Blackwell, (1984)

[11] Holmes. J., Introduction to Sociolinguistics. $4^{\text {th }}$ ed. Routledge. New York, (2013)

[12] Hsu. Jia-ling., Englishization and language change in modern Chinese in Taiwan, World Englishes 13(2) (1994), 167-184, https://doi.org/10.1111/j.1467-971x.1994.tb00305.x

[13] Hudson. R. A., Sociolinguistics. $2^{\text {nd }}$ ed. Cambridge: Cambridge University Press, (2001)

[14] Hymes, Towards Communicative Competence, Philadelphia: University of Philadelphia Press, (1972)

[15] Labov. W., Sociolinguistic Patterns. Philadelphia PA: University of Pennsylvania Press(1972)

[16] Labov. W., Field methods of the project on linguistic change and variation, In Language in Use: Readings in Sociolinguistics, J. Baugh \& J. Sherzer (eds), 28-66. Englewoods Cliffs NJ: Prentice Hall. Marang, Journal of Language and Literature. 24(1984), 82-95.

[17] Najim. I., The Foreignized Translation: One Approach to Respect and Preserve the Culture of the Other, In Journal of College of Education For Women. 24 (2)(2013), 500-511.

[18] Ojidahun. C. O., The Domestication of English in Femi Osofisan's Drama: A Sociolinguistic Perspective, In Olanipekun, S., Onanbanjo, E., \& Olayemi, M., (2014)

[19] Otor. A.J., Towards Domestication of English Language in Nigeria: Prospects and Challenges, In International Journal of Humanities and Social Sciences, 3(7)(2015), 165-168.

[20] Pereira. C., Waves of Arabization and Vernacular of North Africa, In The Routledge Handbook of Arabic Linguistics, (2017), 488- 503, https://doi.org/10.4324/9781315147062-28

[21] Rosman. A. \& Rubel. G., Translating Cultures: Perspectives on Translation and Anthropology. Oxford: New York, (2003), https://doi.org/10.5040/9781474215879

[22] Salman. M. \& Mansoor. S., English Loanwords in Iraqi Arabic, In Cihan University-Erbil Scientific Journal. 1(1)(2017), 271-294.

[23] Schugurensky. D., Higher education restructuring in the era of globalization: Toward a heteronomous model. In R. F. Arnove \& C. A. Torres (Eds.), Comparative education: The dialectic of the global and the local (3rd ed., pp. 257-276). Lanham, MD: Rowman \& Littlefield, (2007)

[24] Venuti. L., The translator's invisibility: A history of translation, London: Routledge, (1995)

[25] Wright. S., Language Policy and Language Planning: From Nationalism to Globalisation, Houndmills: Palgrave Macmillan, (2004) 


\section{Appendix (1):}

Table of Domesticated English Expressions Used by the Najafi Informants

\begin{tabular}{|c|c|c|c|}
\hline No & Expression in Arabic & $\begin{array}{l}\text { Expression } \\
\text { transcribed }\end{array}$ & Expression in English \\
\hline 1 & اتاجمنت & Attachment & Attachment \\
\hline 2 & 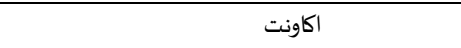 & Account & Account \\
\hline 3 & اكتبله نوت & iktiblah note & Write a note to him \\
\hline 4 & اكسس & Access & Access \\
\hline 5 & انبوكس & Inboox & Inbox \\
\hline 6 & انترنيت & Internet & Internet \\
\hline 7 & انترنيت اكسبلورر & Internet explorer & Internet explorer \\
\hline 8 & انتي فايروس & Antivirus & Antivirus \\
\hline 9 & انيستكرام & Instagram & Instagram \\
\hline 10 & اوبشنز & Obtions & Options \\
\hline 11 & اوت بوكس & Outbox & Outbox \\
\hline 12 & اوف لاين & Offline & Offline \\
\hline 13 & اون لاين & Online & Online \\
\hline 14 & اي ميل & e-mail & e-mail \\
\hline 15 & ايكونات & Iconat & Icons \\
\hline 16 & بارتشنات & bartitionat & Partitions \\
\hline 17 & باس وورد & bassword & Password \\
\hline 18 & باور بوينت & bower boint & Power point \\
\hline 19 & براوزر & Browser & Browser \\
\hline 20 & بروفايل & brofile & Profile \\
\hline 21 & 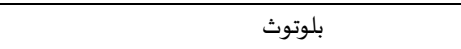 & Bluetooth & Bluetooth \\
\hline 22 & بلي ستور & blay store & Play store \\
\hline 23 & تلي & Teli & Tele $=$ telegram \\
\hline 24 & تويتر & Tweeter & Tweeter \\
\hline 25 & 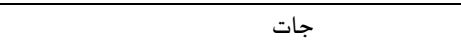 & Chat & Chat \\
\hline 26 & الجمي ميل & Gmail & Gmail \\
\hline 27 & جييك & Chei'ik & Check \\
\hline 28 & داون لود & Download & Download \\
\hline 29 & درافت & Draft & Draft \\
\hline 30 & دزاين & Design & Design \\
\hline 31 & دزاينر & Designer & Designer \\
\hline 32 & دزلي مسج & dizli message & Send me a message \\
\hline 33 & دسك & Disc & Disc \\
\hline 34 & دلفري & Delivery & Delivery \\
\hline 35 & 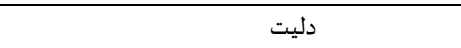 & Delete & Delete \\
\hline 36 & دوكيومانتس & Documents & Documents \\
\hline 37 & رام & Ram & Ram \\
\hline 38 & 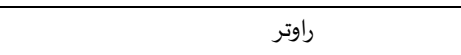 & Router & Router \\
\hline 39 & ريستارت، رستت الحاسبة او الموبايل & Restart & Restart \\
\hline 40 & ريفرش & Refresh & Refresh \\
\hline 41 & سبام & Sbam & Spam \\
\hline 42 & سبيسسس & Sbaces & Spaces \\
\hline 43 & سكرين شوت & Screen shot & Screen shot \\
\hline 44 & سكنر & Scanner & Scanner \\
\hline
\end{tabular}




\begin{tabular}{|c|c|c|c|}
\hline 45 & سلايدات & Slaidat & Slides \\
\hline 46 & سوفت وير & Software & Software \\
\hline 47 & سي بي يو & Ci bi you & $\mathrm{CPU}$ \\
\hline 48 & سي دي & $\mathrm{CD}$ & $\mathrm{CD}$ \\
\hline 49 & سي في & $\mathrm{CV}$ & $\mathrm{CV}$ \\
\hline 50 & سيرج & Search & Search \\
\hline 51 & سيلفي & selfi & Selfi \\
\hline 52 & سيند & Send & Send \\
\hline 53 & سييفت & Sei'avit & Save \\
\hline 54 & شت داون & Shut down & Shut down \\
\hline 55 & فان & Fan & Fan \\
\hline 56 & فايبر & fiber & Viber \\
\hline 57 & فايروس & Virus & Virus \\
\hline 58 & فايل & File & File \\
\hline 59 & فديو & Video & Video \\
\hline 60 & فرمت الموبايل & Fermit el mobile & Format the mobile \\
\hline 61 & فلاش & Flash memory & Flash memory \\
\hline 62 & فولدر & Folder & Folder \\
\hline 63 & فيس بوك & Fiacebook & Facebook \\
\hline 64 & كابجر & Capture & Capture \\
\hline 65 & كارد & Card & Card \\
\hline 66 & كاميرة & Camerah & Camera \\
\hline 67 & 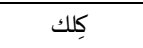 & Click & Click \\
\hline 68 & كليب & Clip & Clip \\
\hline 69 & كنك & Cennek & Connect, he connects \\
\hline 70 & كوبي بيست & Coby-baste & Copy-paste \\
\hline 71 & كود & Code & Code \\
\hline 72 & كي بورد & Keyboard & Keyboard \\
\hline 73 & كيبل & Cable & Cable \\
\hline 74 & 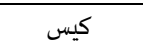 & Case & Case \\
\hline 75 & ل ابتوب & Labtob & Laptop \\
\hline 76 & لوَّد،يلوّد & Load & Load \\
\hline 77 & ل لوك ان & $\log$ in & $\log$ in \\
\hline 78 & لوك اوت & Log out & Log out \\
\hline 79 & ماوس & Mouse & Mouse \\
\hline 80 & يوتيوب & Youtube & You tube \\
\hline 81 & مس كول & Miss call & Missed call \\
\hline 82 & مسج & Message & Message \\
\hline 83 & ماسنجر & Mazinger & Messenger \\
\hline 84 & مونيتر & Monitor & Monitor \\
\hline 85 & منيو & Menu & Menu \\
\hline 86 & 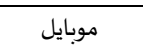 & Mobile & Mobile \\
\hline 87 & 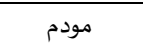 & Modem & Modem \\
\hline 88 & ميل & Mail & Mail \\
\hline 89 & هارد وير & Hardware & Hardware \\
\hline 90 & هاكر & Hacker & Hacker \\
\hline 91 & هيدفون & Headphone & Headphone \\
\hline 92 & واتس اب & Wats app & Wats app \\
\hline
\end{tabular}




\begin{tabular}{|c|c|c|c|}
\hline 93 & واي فاي & Wifi & Wifi \\
\hline 94 & وايرليس & Wireless & Wireless \\
\hline 95 & الياهو & Yahoo & Yahoo \\
\hline 96 & يمسكل & imaskel & He does a missed call \\
\hline 97 & يو اس بي & USB & USP \\
\hline 98 & يو بي اس & UBS & UBS \\
\hline 99 & اسوي جات & asawi chat & I chat \\
\hline 100 & يكبجر & ikabchir & He captures \\
\hline
\end{tabular}

\section{The Interview}

\section{Appendix (2): The Interview}

Hello Everyone,

This is an interview on using information technology services and impact on society. It consists of a focus group involving ten male participants, 15-30 years old/ ten male participants, 30-50 years old/ ten female participants, 15-30 years old/ ten female participants, 30-50 years old. It consists on ten questions to be answered by the participants as follows:

1. How do you find the service of the mobile, internet, computer, and the social media?

$$
\text { كيف تجد الخدمة التي يقدمها الهاتف الجوال او الحاسوب او الشبكة العنكبوتية او وسائل التواصل الاجتماعي؟ }
$$

2. Which of these do you prefer? Why?

اي من هذه تفضل؟ ولماذا؟

3. Do have an idea how each of these works?

هل لديك فكرة عن عمل هذه الاجهزة والوسائل؟

4. Do know why these device and means are invented?

هل تعرف ما سبب اختراع هذه الاجهة والوسائل؟

5. Can you name some of the mobile applications, computer programs, internet applications or the social media applications that can be of benefit?

هل يمكنك ان تذكر بعض التطبيقات في الهاتف الجوال او برامج الحاسوب او برامج الشبكة العنكبوتية او وسائل التواصل الاجتماعي التي لها فائدة؟

\section{Appendix (3): The Questionnaire}

الاستبانة

السلام عليكم ورحمة الله وبركاته،

يود الباحث ان يجري دراسة حول الكلمات في اللغة الانجليزية التي يستخدمها متحدثو اللغة العربية العر اقيون في مجال تقنيات المعلوماتية الحديثة والتي تتمثل بمفردات الحاسوب والهاتف الجوال والشبكة العنكبوتية ووسائل التواصيل الاجتماعي.

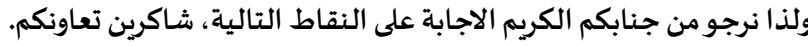


ع- اذكربعض الكلمات الانجليزية التي نستخدمها في الحياة اليومية في مجال وسائل التواصل الاجتماعي باللهجة العر اقية:

ه- عنما تريد ان تستخدم اي مفردة تتعلق بأحد المجالات المذكورة مثلا في مجال الحاسوب او الهاتف الجوال او الشبكة العنكبوتية اووسائل التواصل الاجتماعي

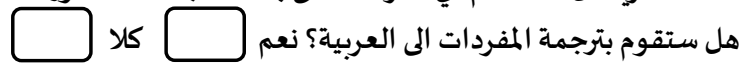

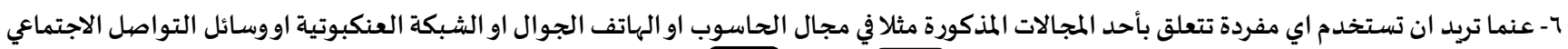

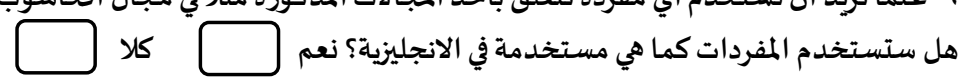

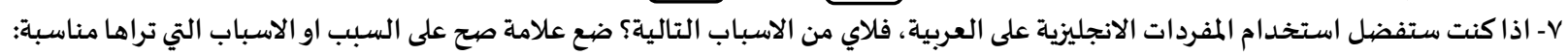
- اللغة الانجليزية اسهل من المفردات المترجمة للعربية

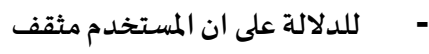

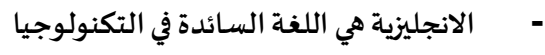

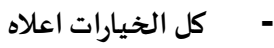
- - ل

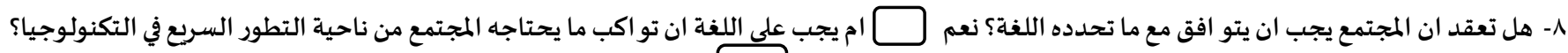

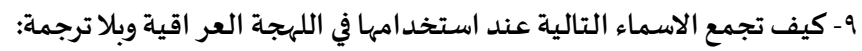

CD.................................

Case...............................

E-mail............................

Power............................

Laptop.

Keyboard........................

Programme
Missed call.

Message.

Ram

Headphone.

Antivirus.

Icon.

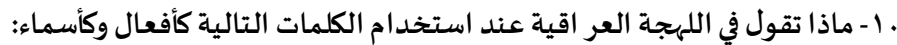

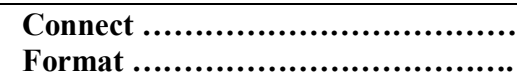

Download

Save

Cancel

Chat

\section{Message}

Delete

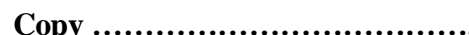

Missed call

Paste

Facebook 